\title{
UN NUEVO EJEMPLAR ILUSTRADO DE LOS MORALES DE GREGORIO MAGNO (B.A.H. COD. 1) DEL SIGLO XIII, INEDITO
}

\author{
POR \\ SOLEDAD DE SILVA Y VERASTEGUI \\ Universidad del País Vasco
}

The codex was copied and illustrated in the early decades of the XIII century, in the scriptorium of San Millan de la Cogolla. This scriptorium was at this time going through a renewed age of splendour which fully coincided in time with the intense literary work carried out by Gonzalo de Berceo. In this paper we analyse the miniatures and decorative initials from an iconographic and a stylistic perspective, and we identify its authors as being the same artists who illustrated the celebrated Biblia de San Millan (B.A.H. cod. 2 and 3).

Una de las obras más difundidas en la Península como en el resto de Europa en la Edad Media es sin lugar a dudas los Morales de San Gregorio Magno. Escritos por el célebre papa a requerimientos de San Leandro, obispo de Sevilla, este libro gozó en la España medieval de una larga y profunda tradición como atestiguan todavía numerosos ejemplares y fragmentos que aún se conservan, dos del siglo Ix, nueve del siglo $\mathrm{x}$, tres del siglo XI, otros tres del siglo xII, dos del siglo XIII, tres del siglo xIV, y cinco copias del siglo xV, algunos de ellos bellamente ilustrados ${ }^{1}$. En-

\footnotetext{
1 Los menciona M. C. Díaz y Díaz en Libros y librerías en la Rioja altomedieval, Logroño, 1991, 2.a ed., págs. 333-334, nota 1. Por su utilidad los recogemos aquí y añadimos a la lista de este autor los ejemplares del Museo Episcopal de Vich (siglo xI), San Isidoro de León (siglo XII), Catedral de Zaragoza (siglo xII) y Valencia (siglo xIV), tres copias de la Biblioteca Nacional (siglo xv) y dos del Monasterio del Escorial (siglo xv): siglo Ix. 1. Madrid Archivo Histórico Nacional, cod. $1452 \mathrm{Bl}$ probablemente Córdoba. 5 folios. 2. Barcelona. Biblioteca Central de Cataluña s.n. siglo Ix (?), probablemente Urgel. 1 folio.-Siglo x. 1*. Manchester, John Rylands Library, 83, año 914. Gómez Cardeña (Burgos). 2*. Madrid, Biblioteca Nacional, 80, año 945. Florentius. Valeránica (Burgos). 3. León, San Isidoro, 1, año 951 (Baltarius), Sahagún- Palencia. 4. Barcelona, Archivo Capitular, 102, siglo xm. Región Burgos. 5*. Madrid, Biblioteca de la Academia de la Historia, cod. 5, h. 960-970. San Millán. 6. Toledo, Biblioteca Capitular, 11.4-5, siglo x, probablemente Toledo. 7. Santiago Colección M. Díaz, cod. 2, siglo xm. San Millán. 1 folio. 8. Zaragoza. Colección privada, n. ${ }^{\circ}$ 6, siglos X-Xi. Región navarra. 14 folios. 9. León. Archivo Histórico Diocesano. fondo Bravo, n. ${ }^{\circ}$, siglo x. Región leonesa. Otero de Dueñas. 1 folio.-Siglo xi. 1. Barcelona, Colección privada, siglo xi. Castellano. 2. Museo Episcopal de Vich, 26. 2 historias ornamentadas. 3. Madrid. Archivo Histórico Nacional, cod. 1452 B11. Región castellana. 1 folio.-Siglo xiı. 1. Calahorra. Archivo Catedral, cod. 3, h. 1140. 2. León, San Isidoro. Moralia in Job, 10. Petrus monachus Satusnovalis. 3. Zaragoza, Archivo de la Catedral, siglo xiI.-Siglo xiII. 1. Madrid, Biblioteca de la Academia de la Historia, cod. 1, siglo xiII. 2. Burgo de Osma, Biblioteca Catedral, 177 A-B-C, siglo xIII.-Siglo xIv. 1. Escorial, Biblioteca del Monasterio, b.1.5., siglo xiv. 2. Madrid, Biblioteca del Palacio Real, 2 e 2, siglo xIv. 3. Valencia, Catedral, ms. 244, siglo xIv.-Siglo xv: 1. Madrid, Biblioteca Nacional, ms. 12720, siglo xv. 2. Madrid, Biblioteca Nacional, Ms. 12735-36, siglo xv. 3. Madrid, Biblioteca Nacional, vitr. 17-6, siglo xv. 4. El Escorial, R.II.8, siglo xv. 5. El Escorial, S.I.11, siglo xv.-Numerosísimos más son los códices de los Morales que se han perdido como atestiguan los documentos e inventarios que conservamos de estos siglos.
} 
tre ellos ha llamado recientemente nuestra atención el magnífico ejemplar que custodia la Academia de la Historia (cod. 1) por su rica ilustración. Puesto que ésta ha pasado hasta ahora inadvertida a los historiadores del arte nos proponemos en este artículo darla a conocer.

El códice es obra copiada en el monasterio de San Millán de la Cogolla a principios del siglo $\mathrm{XIII}^{2}$. El viejo scriptorium atraviesa en esta época un nuevo periodo de esplendor basado por una parte en su renovación al incorporar obras nuevas allí transcritas como la Historia Scholastica de Pedro Comestor (B.A.H., cod. 11) o colecciones de Sermones o cadenas morales tan difundidas en aquellos siglos, pero también al sacar copias «actualizadas» de los antiguos fondos de su Biblioteca. Este fue el caso de la célebre Biblia de San Millán (B.A.H., cod. 2 y 3), de las Vitae Patrum (B.A.H., cod. 10) y de los Morales que nos ocupan ${ }^{3}$. Conservamos sobre todo los modelos que sirvieron a estos dos últimos manuscritos, las Vitae Patrum (B.A.H., cod. 13) y los Morales (B.A.H., cod. 5) respectivamente, ambos copiados en el escritorio monástico en el siglo $\mathrm{x}^{4}$. Custodiados desde entonces como auténticas reliquias de la literatura de edificación es evidente que estos manuscritos seguían alimentando dos siglos después la espiritualidad de los monjes como testimonian numerosas huellas de su utilización en esta época y en concreto su nueva transcripción ${ }^{5}$.

Desde el punto de vista artístico llama la atención al cotejar ambos manuscritos del siglo x y XIII las diferencias en su ornamentación. El viejo ejemplar que hoy conservamos incompleto apenas se decoró. Se destacaron en él simplemente algunas iniciales coloreadas y se adornaron otras con motivos muy sencillos como puntos, trazos rectilíneos o en $\mathrm{V}$ y pequeñas hojas estilizadas. $\mathrm{La}$ más elaborada de todas ellas es la inicial del folio $141 \mathrm{v}$ con decoración de entrelazo formando un típico trenzado. Ignoramos las razones de esta sobriedad decorativa, más teniendo en cuenta que por los mismos años se ornamentaron en el escritorio emilianense preciosos códices como las Homilias de Ezequiel del mismo autor San Gregorio Magno (B.A.H., cod. 38) o el magnífico ejemplar de la Expositio Psalmorum de Casiodoro (B.A.H., cod. 8) entre otros ${ }^{6}$. Por ello sorprende enormemente que al sacarse una nueva copia de este ejemplar en el siglo xiII se ilustrase con varias miniaturas y una rica decoración de iniciales que paso seguidamente a considerar.

\section{Las miniaturas}

\section{Un obispo ¿Tajon de Zaragoza? y dos clérigos (fol. 1). (Fig. 1)}

La miniatura encabeza la famosa carta que Tajon, obispo de Zaragoza, dirige al arzobispo de Toledo, Eugenio, acompañando el envio de su recensión a la obra de San Gregorio que somete a su consideración y que se inicia así: «Sanctissimo ac venerabili domino meo Eugenio Episcopo toletane urbis Taius ultimus servus servorum dei Cesaragustanus Aepiscopus». La carta ha sido copiada también del códice (B.A.H. 5) del siglo x que nos la transmite lo mismo que otros dos ejem-

2 Sobre este códice véase Loewe, G.; Hartel, W., Bibliotheca Patrum Latinorum Hispaniensis, 1, Viena, 1886, (ed. Hildesheim, 1973, pág. 483)., Pérez Pastor, C., "Indice de los títulos de los códices procedentes de los Monasterios de San Millán de la Cogolla y San Pedro de Cardeña, existentes en la Biblioteca de la Real Academia de la Historia", en Boletín de la Real Academia de la Historia, 53, 1908. págs. 469-470; Díaz y Díaz, M. C., Libros y librerías, op. cit., pág. 339; Idem, "Notas de Bibliotecas de Castilla en el siglo xiI", en Colloque de la Casa de Velázquez, 1981, pág. 8.

3 Díaz y Díaz, M. C., "Notas de Bibliotecas...”, op. cit., págs. 7-9.

4 Díaz y Díaz, M. C., Libros y librerías, op. cit., págs. 122- 127 y 133-140.

5 Sobre estos aspectos, Díaz y Díaz, M. C., "Notas de Bibliotecas...», op. cit., págs. 8 y 9.

6 Hemos tratado sobre la ilustración de estos manuscritos en nuestro libro Iconografía en el Reino de Pamplona-Nájera del siglo x, Pamplona, 1984, págs. 77. 85 y 150; sobre el manuscrito (B.A.H., cod. 8) véase más recientemente, Idem, "Los monasterios riojanos y el arte de la miniatura en el alto medioevo", en III Semana de Estudios Medievales, Nájera 3-7, Agosto, 1992, Logroño, 1993, págs. 224-225. 
plares de los «Moralia in Job» de esta misma centuria, ambos emparentados con nuestro viejo manuscrito por su proximidad geográfica, el códice copiado por Gómez en Cardeña en el año 914 y el ejemplar realizado en el año 945 por Florencio de Valeránica ${ }^{7}$. Es sabido el importante papel que se le atribuye al obispo zaragozano en la difusión de la obra del Papa Gregorio en España. El mismo realizó, al parecer, un viaje a Roma donde buscó afanosamente sus obras de difícil consulta en la Península las cuales copió de su propia mano. Después, según se deduce de la carta a Eugenio, llevó a cabo un verdadero esfuerzo editorial introduciendo resúmenes y prefacios que aclarasen mejor el contenido del libro ${ }^{8}$. Todos estos manuscritos nos transmiten además a continuación la narración de una visión que se supone que tuvo Tajon en Roma, a propósito de los «Moralia» del Papa, entresacada según los autores de la Crónica mozárabe del año $754{ }^{9}$. Puesto que otros códices hispanos de su misma categoria no incluyen estas piezas introductorias hemos de concluir la importancia que para esta región castellano-riojana tuvieron estos textos tajonianos. Ello puede apoyar nuestra hipótesis acerca del personaje figurado en la miniatura que pudiera representar a Tajon, obispo de Zaragoza acompañado de otros dos clérigos, uno de ellos arrodillado a sus pies, recibiendo su bendición. El prelado, a quien distingue los ornamentos episcopales y el báculo pastoral habría sido representado como autor de la epístola que ilustra ${ }^{10}$. La iconografía se inspiraría de este modo en una larga tradición ilustrativa propia del género epistolar, como hemos explicado en otros lugares, cuyos orígenes remontan a la Antigüedad y que fue ampliamente aplicada en el arte medieval ${ }^{11}$.

\section{San Gregorio Magno como autor (fol. 2). (Fig. 2)}

Esta miniatura está colocada también al frente de otro texto epistolar, la carta que envía el Papa Gregorio a Leandro, obispo de Sevilla, dedicándole los «Moralia» y que incluyen todos los manuscritos. La imagen nos presenta al autor del libro inspirado por el Espíritu Santo simbolizado por la paloma y acompañado de su escriba, el diácono Pedro, conforme a una tradición iconográfica muy antigua que remonta por lo menos a la época carolingia.

$\mathrm{Ni}$ el Liber Pontificalis redactado a fines del siglo vI, ni Beda el Venerable (+ 735) en los datos biográficos que recoge del santo Papa mencionan ninguna intervención divina a propósito de sus escritos. Es precisamente un anónimo monje anglosajón el que a principios del siglo viII nos proporciona la primera noticia acerca de una asistencia divina que convirtió al Papa Gregorio en un autor cuasi inspirado. El texto nos ha llegado a través de un manuscrito de S. Gall de h. 713, donde a propósito de las Homilías sobre Ezequiel, el autor evoca los cielos abiertos y la aparición de la paloma divina con estos términos «Cui similiter celi aperti sunt (...) hoc de illo patet cito legentibus (...) Ita super hunc virum». Dei vidisse quidam dicitur de suis satis et familiaribus albam sedisse columbam, cum iu praedictum Ezechialem fecit omelias» ${ }^{12}$. Es muy posible que este relato se inspire en alguna leyenda originada en Roma. El episodio fue recogido después por otros

bió-

7 Díaz y Díaz, M. C., Libros y librerías, op. cit., pág. 126. El ejemplar de Valeránica ostenta una interesante decoración sobre la cual puede verse Williams, J., "A contribution to the history of the Castilian Monastery of Valeranica and the scriba Florentius", en Madrider Mitteilungen 11, 1970, págs. 231-248; Idem, "The "Moralia in Job" of 945: Some iconographie sources", en Archivo Español de Arqueología, XLV-XLVII, 1972-1974, págs. 223-249; Idem, La miniatura española en la Alta Edad Media, Madrid, 1987, págs. 58-60; Idem, The Illustrated Beatas a Corpus of the Illustrations of the Comentary on the Apocalypse, I, Introduction, London, 1994, págs. 78-79.

8 Díaz y Díaz, M. C., Libros y librerías, op. cit., págs. 333-350.

9 Ibidem, pág. 335.

10 Dificulta esta hipótesis de interpretación del personaje la ausencia de la mitra episcopal.

11 Véase, mi libro Iconografía del siglo $x$, op. cit., págs. 230-245.

12 Croquison, J., "Les origines de l'Iconographie Grégorienne», en Cahiers Archéologiques, XII, 1962, págs. $254-255$. 


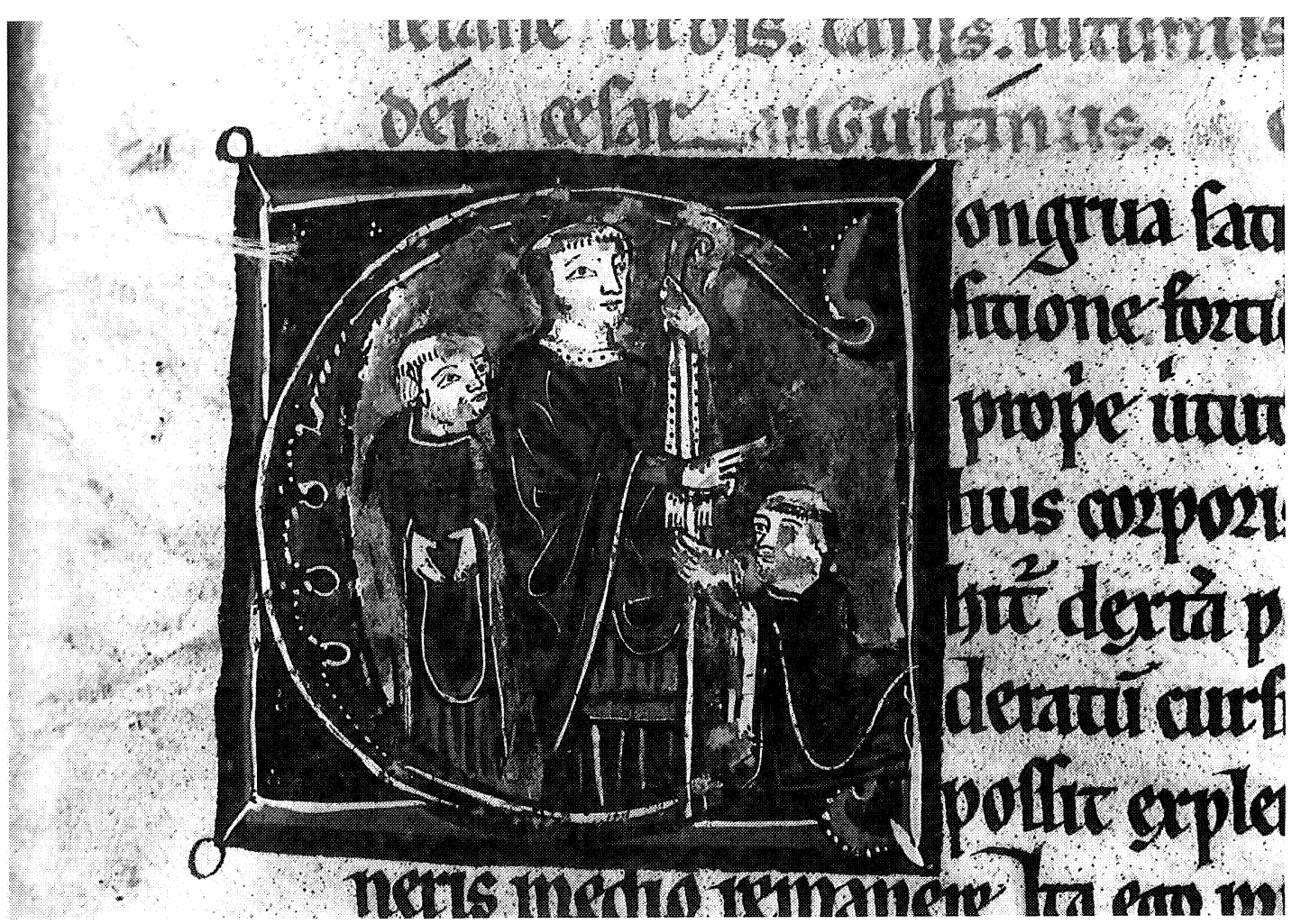

Fig. 1. Un obispo ¿Tajon de Zaragoza? y dos clérigos. Morales de San Gregorio. (Madrid, B.A.H., cod. 1, fol. 1.)

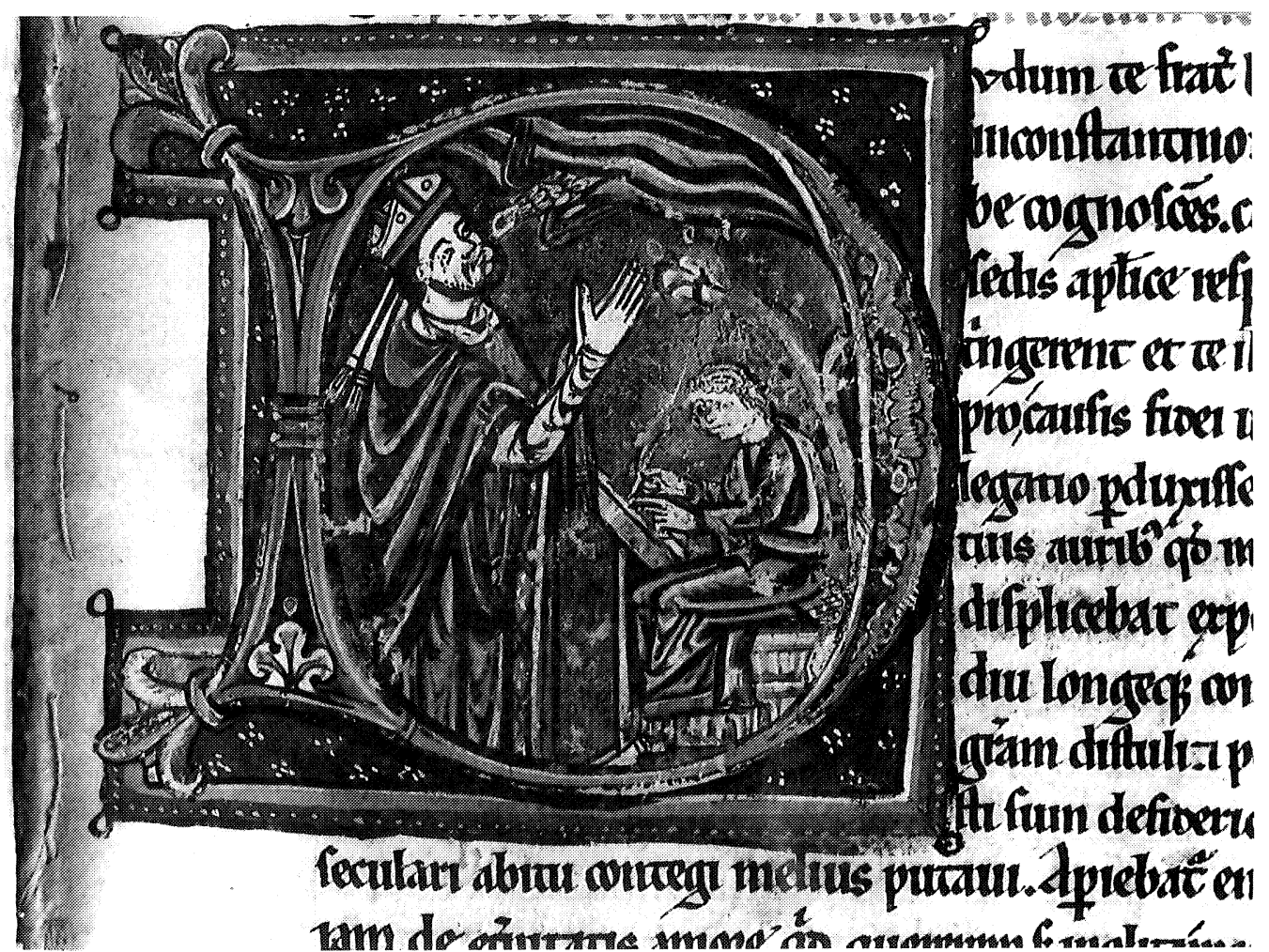

Fig. 2. San Gregorio Magno. Morales de San Gregorio. (Madrid, B.A.H., cod. 1, fol. 2.) 
grafos del Papa Gregorio amplificándolo con más detalles. Así el monje casinense Pablo Diácono, a principios del siglo Ix, introduce un testigo de esta visión, el escriba quien contempla, mientras San Gregorio redacta sus comentarios al profeta Ezequiel, cómo una paloma se ha posado sobre su cabeza y ha apoyado el pico en la boca del autor divinamente inspirado. Unos años después, h. 873-875, el diácono romano Juan que vuelve a escribir otra nueva y larga biografía de San Gregorio, esta vez por orden del Papa Juan VIII, aunque no añade nada esencial al relato de su predecesor, afirma que según el diácono Pedro, confidente de Gregorio y su interlocutor en los "Diálogos» se veía muy a menudo -frecuentemente dice-, al Espíritu Santo en forma de paloma sobre su cabeza ${ }^{13}$. De este modo la imagen del autor inspirado se convirtió en un clásico de la iconografía gregoriana en su tiempo. Las más antiguas ilustraciones nos las ofrecen ya un Homiliario norte italiano fechado a fines del siglo viII (Berlín, Deutsche Staatsbibliothek ms. Phill 1676, fol. 25) -el códice Egino-, que nos presenta al Papa romano inclinado sobre el escritorio redactando sus Homilías que sostiene su escriba, en la misma actitud que los Evangelistas ante su pupitre ${ }^{14}$. Bajo la gran arcada que lo cobija aparece la paloma divina, símbolo del Espíritu Santo. La imagen del autor inspirado la encontramos de nuevo en un ejemplar del «Liber Regulae pastoralis» datado en el segundo cuarto del siglo ix (Roma, Archivo de Santa María la Mayor, c 1.5) que representa a Gregorio sentado y la paloma divina cerca de su oído. Sin embargo uno de los retratos gregorianos más célebres nos lo proporciona el magnífico Sacramentario (París, Bibl. Nat. lat. 1141) obra magna del arte carolingio, fechado hacia el año 875. El frontispicio representa a Gregorio en el centro de la composición sentado en un trono adornado con rica pedrería, mientras a su derecha la paloma desciende del cielo, figurado por una serie de nubes, acercándose al Papa que vuelve la cabeza hacia este lado. A sus pies separados por un velo dos personajes representan el de la izquierda al diácono Pedro, testigo del prodigio milagroso y el de la derecha a uno de sus biógrafos Juan Diácono. J. Croquison que ha estudiado los orígenes de la iconografía gregoriana explica la introducción de este último personaje en esta imagen por influencia de ]a biografía de este autor que recoge en el Prólogo de la Vita el siguiente distico que él mismo dedica a San Gregorio: "Et quia mortalis desunt commercia carnis, / da mihi sub pedibus posse jacere tuis» ${ }^{15}$. A parte de esta imagen excepcional, la iconografía gregoriana más antigua representa a un solo personaje junto al Papa que es a la vez el escriba y el testigo de la aparición de la misteriosa paloma, es decir, el diácono Pedro. Así figura en un ejemplar de los «Moralia» (Montecassino, ms. 73) de principios del siglo xi donde delante del Papa se sitúa un diácono en pie, recognoscible por su estola y a quien el miniaturista ha otorgado símbolo de santidad en perfecta correspondencia con la inscripción que le identifica como S. Petrus. En esta composición la tradicional paloma ha sido sustituida por un ángel, símbolo también de la divina inspiración ${ }^{16}$. Una imagen elocuente de la iconografía clásica gregoriana nos la proporciona el magnífico ejemplar del «Registrum Gregorii» (Treveris, Stadbibliothek) de fines del siglo x en la que el Papa Gregorio aparece sentado ante su escritorio apoyando la mano izquierda sobre el manuscrito abierto mientras en la derecha sostiene un libro. La paloma divina se ha posado esta vez sobre el hombro derecho acercándose a su oído. Detrás figura el escriba que contempla esta divina aparición a través del agujero que ha abierto con su pluma en la cortina que lo separa del autor ${ }^{17}$. La imagen es una transposición literal del relato de Pablo Diácono, monje casinense, ya comentada ${ }^{18}$.

\footnotetext{
13 Ibidem.

14 Cfr. Boinet, La miniatura carolingienne, Paris, 1913, pl. LXLVII B.

15 Croquison, J., op. cit., pág. 256.

16 Ibidem, pág. 261.

17 Grodecki, L.; Mutherich, F.; Taralon, J.; Wormald, F.: El siglo del año mil, Madrid, 1966, pág. 129, lám. 118.

18 Una descripción de esta visión en Croquison, J., op. cit., pág. 255, nota 2.
} 
Las imágenes altomedievales mencionadas nos permiten identificar ahora los elementos iconográficos que aparecen en la escena de nuestro ejemplar de los «Moralia». No cabe la menor duda de que se trata de un retrato del autor del libro, San Gregorio, que aparece en pie con las manos juntas atento a las inspiraciones divinas que le llegan a través de la paloma que, como en el manuscrito carolingio (París, Bibl. Nat. lat. 1141) desciende del cielo, representado igualmente por una masa de nubes azules y blancas. El pontífice aparece vestido con alba y casulla amplia. Lleva la mitra sobre la cabeza y un manipulo en la mano izquierda. Al lado, en tamaño ostensiblemente menor, figura el escriba completamente concentrado en su función, esta vez al margen según parece de la milagrosa intervención. La miniatura, a dos siglos de distancia de los últimos modelos señalados, recoge pues los elementos clásicos de la iconografía gregoriana, como es la paloma alusiva a la divina inspiración que recibe el autor y la presencia del escriba. Sin embargo otros aspectos, como el del copista ajeno a esta misteriosa aparición supone una transformación de los elementos clásicos de la visión gregoriana, transformación que ya se registra en el arte desde el siglo xi. Así lo testimonia una placa de marfil, que posiblemente sirvió de encuadernación de un Sacramentario, conservada en Viena (Kunsthistorisches Museum, procedente del monasterio austríaco de Heiligenkreuz) que representa a Gregorio completamente aislado en el primer registro, escribiendo en un manuscrito, y la paloma sobre su oído. En la zona inferior aparecen tres personajes en actitud de escribir absolutamente aplicados en su trabajo, totalmente ajenos a la escena de la aparición, como el escriba del ejemplar de los "Moralia» que nos ocupa ${ }^{19}$. Como hemos visto esta imagen del Papa San Gregorio hunde sus raíces en una larga tradición iconográfica y sirve de presentación del libro al mostrarnos el retrato de su autor, conforme a uno de los usos más frecuentes en la ilustración del libro en la época medieval ${ }^{20}$.

\section{Job y el demonio (fol. 5). (Fig. 3)}

Las siguientes miniaturas representan tres episodios distintos de la vida Job, «Job y el demonio», «la visita de su mujer y sus amigos», $\mathrm{y}$ «Job y el ángel». Aparentemente no existe ninguna relación directa con los textos que ilustran por lo que es muy posible que el miniaturista se haya inspirado en tres de las escenas más difundidas de la vida de este justo en el arte medieval, las dos primeras posiblemente tomadas de algún ejemplar bíblico, mientras que la última, como ahora veremos, parece responder a una invención del arte medieval.

La primera nos presenta a Job desnudo, con su cuerpo cubierto de llagas, sentado en el muladar. Frente a él se sitúa el demonio, un grotesco personaje de cuerpo humanoide peludo y cabeza de monstruo. La imagen se corresponde desde el punto de vista iconográfico con el pasaje narrado en Job 2, 7: «Con eso, partiendo Satán de la presencia del Señor hirió a Job con una úlcera maligna, desde la planta del pie hasta la coronilla de la cabeza» tal como de hecho nos han transmitido varias Biblias hispánicas medievales. Este texto ha sido precisamente ilustrado con una imagen parecida en la Biblia de San Millán obra rigurosamente contemporánea de nuestro manuscrito ya que ambos fueron realizados en el mismo escritorio e ilustrados, como más adelante veremos, por los mismos miniaturistas. La escena de la Biblia presenta a Job semidesnudo, sentado en el estercolero y atormentado por el diablo que le hiere con un hierro en la planta de los pies, el cual a falta de espacio ha sido situado en el margen inferior del folio. El demonio adopta rasgos parecidos al del ejemplar de los "Moralia» y lleva alas aludiendo a su origen angélico, de-

\footnotetext{
19 Ibidem, pág. 261.

20 Sobre este tema son esenciales los trabajo de Spatharakis, J., The portrait in Byzantine illuminated manuscripts, Leiden, 1976; Salter, E. y Pearsall, D., «Pictorial Illustration of late Medieval poetic texts the role of the frontispiece or prefactory picture", en Medieval iconography and narrative, A Symposium, Odense, 1980, págs. 100-123.
} 
talle que no podemos detectar en la miniatura que nos ocupa por su mal estado de conservación. Esto mismo nos impide también comprobar, si como en el caso de nuestra Biblia, el diablo ostenta en la mano el mencionado instrumento de tortura ${ }^{21}$. La principal diferencia entre ambas imágenes afecta al misterioso personaje nimbado que añade el ejemplar bíblico, cuya presencia hemos de explicárnosla en el posible modelo que inspiró al miniaturista de esta Biblia. Desde los estudios del prof. Williams es sabido que esta Biblia de San Millán pertenece a la misma tradición figurativa que ilustró la Biblia de Florencio y Sancho realizada en el escritorio castellano de Valeránica en el año 960 y su copia realizada en León en 1162 22. Ambas ilustran el texto que venimos comentando con una imagen de Job, en ambos casos vestido y sentado en el estercolero. El demonio que adopta una apariencia distinta en cada ejemplar hiere también a Job con una lanza y aparece un tercer personaje que en este caso es visiblemente una mujer a la que hemos de identificar con su propia esposa ${ }^{23}$.

Sin embargo, la miniatura del ejemplar de los "Moralia», aunque inspirada posiblemente como venimos comentando en algún ejemplar de la Biblia, no ha sido colocada junto al texto correspondiente (Job, 2-7) que figura más adelante en el libro tercero (capítulo III), sino que aparece situada en el libro primero (capítulo I) que alaba la virtud de Job por ser bueno entre los malos, idea con la que aparentemente no tiene relación. Unicamente en sentido figurado cabría ver una alusión a este texto si el miniaturista hubiera tenido la intención de representar a los malos por la figura del diablo, como de hecho sugiere el comentario citando el Apocalipsis II, 13 a propósito de la Iglesia de Pérgamo: «Bien sé donde moras: donde está la silla de Satanás: y allí tienes mi nombre y no negaste mi fe». Este tipo de interpretaciones no fueron infrecuentes en el arte medieval 24 .

\section{Job visitado por su mujer y sus amigos (fol. 215v). (Fig. 4)}

La miniatura representa sobre fondo de oro una de las escenas más divulgadas de la historia de Job en el arte medieval. Job sentado, completamente desnudo dejando al descubierto su cuerpo ulcerado lleva en la mano derecha un tejón con el que se rasca las llagas. Sobre la cabeza ostenta el nimbo propio de los justos. Al lado figura su mujer, vestida con túnica y manto y velo cubriéndole la cabeza y los hombros, y sus tres amigos detrás. La escena es muy parecida a la que figura en la Biblia de San Millán donde se ha representado en tres ocasiones a propósito de Job 2, 9-11, Job 18, 1 y Job 32, 6 25. Llama la atención que la esposa de Job aparezca en las tres es-

21 Lo que queda claro en la imagen es que el diablo no toca para nada los pies de Job a lo que hace referencia el texto y la miniatura de la Biblia. La mano de Satán en el caso de los "Moralia» se aproxima a la mano extendida de Job.

22 Williams, J., "A Castilian tradition of Bible illustration the romanesque Bible form San Millán", en Journal of the Warburg and Courtauld Institutes, 28, 1965, págs. 66-85; Idem, "A model for the Leon Bibles", en Madrider Mitteilungen, 8, 1967, págs. 281-286.

23 El demonio en la Biblia de Valeránica es un misterioso personaje con doble cabeza una vuelta hacia cada lado de modo que se ve su perfil. El cuerpo es único y alado y se nos muestra de frente. Una imagen distinta nos ofrece la Biblia de León que representa un ser antropomorfo peludo también alado con cabeza y garras de animal. Un detalle curioso es que enrolla una serpiente a modo de cinturón. Sobre el diablo en la Biblia de Valeránica puede verse Yarza, J., "Del ángel caído al diablo medieval», en Boletín del Seminario de Arte y Arqueología de Ia Universidad de Valladolid, XLV, 1979, págs. $311-313$.

24 La imagen de Job, como varón junto y temeroso de Dios, ofreciendo sacrificios y víctimas a Yavé enfrentando a Satanás, aparece al comienzo del libro de Job en la Biblia de Lérida a modo de presentación del Libro. Véase Yarza, J., "La Biblia de Lérida, manuscrito de procedencia aragonesa, muestra de la internacionalidad del románicon, en Actas del IV Coloquio de Arte Aragonés (Benasque, 1985), Zaragoza, 1986, págs. 355-374; Idem, "Anotacions iconográphiques a la «Biblia de Lleidam, en Quaderns d'Etudis Medievals, 23-24, 1988, págs. 66-81, especialmente para esta miniatura págs. 69-70.

25 Esta escena no aparece ilustrada en los otros códices bíblicos pertenecientes a esta misma familia, la Biblia de Valeránica del año 960 y la Biblia de León de 1162. 

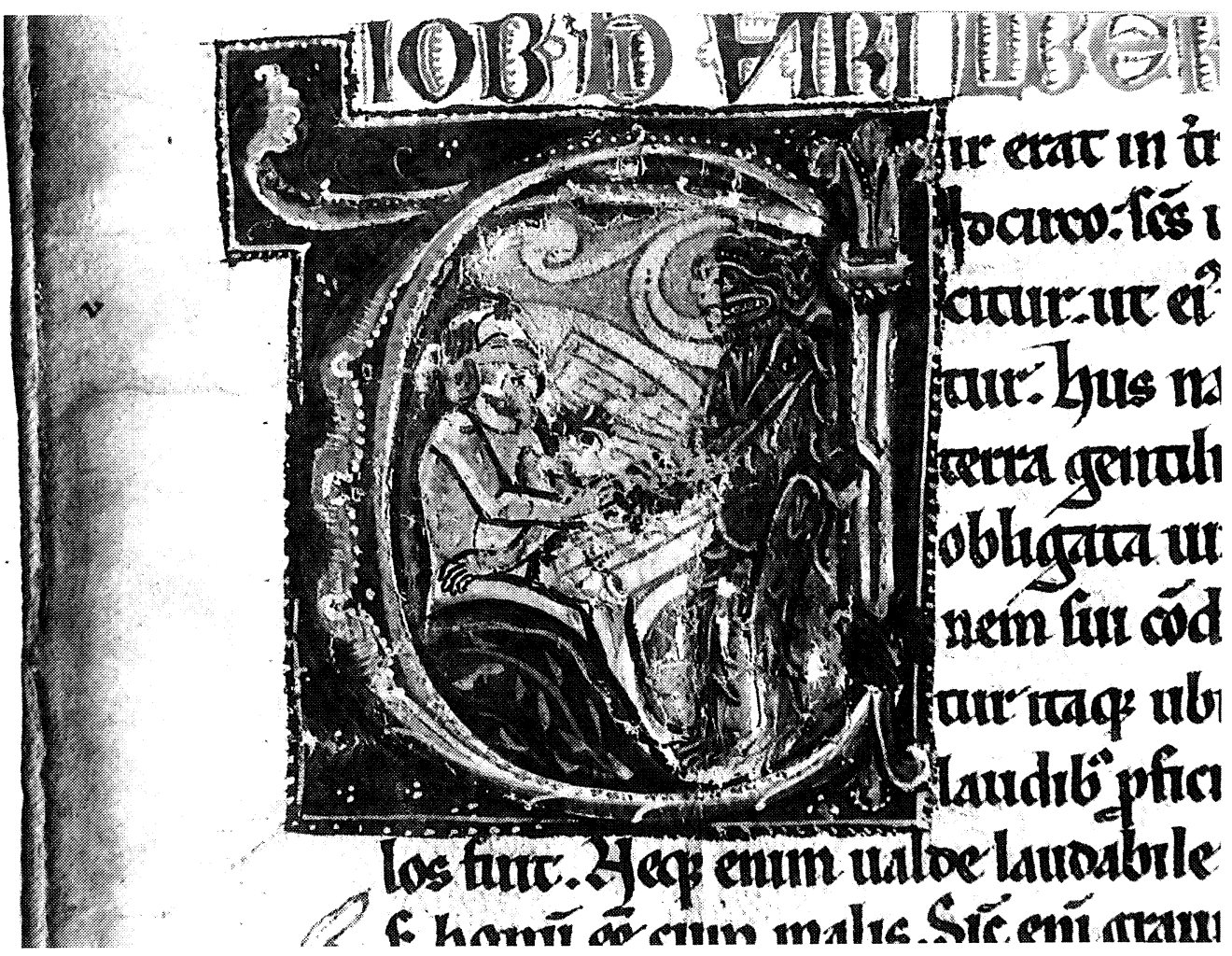

Fig. 3. Job y el demonio. Morales de San Gregorio. (Madrid, B.A.H., cod. 1, fol. 5.)

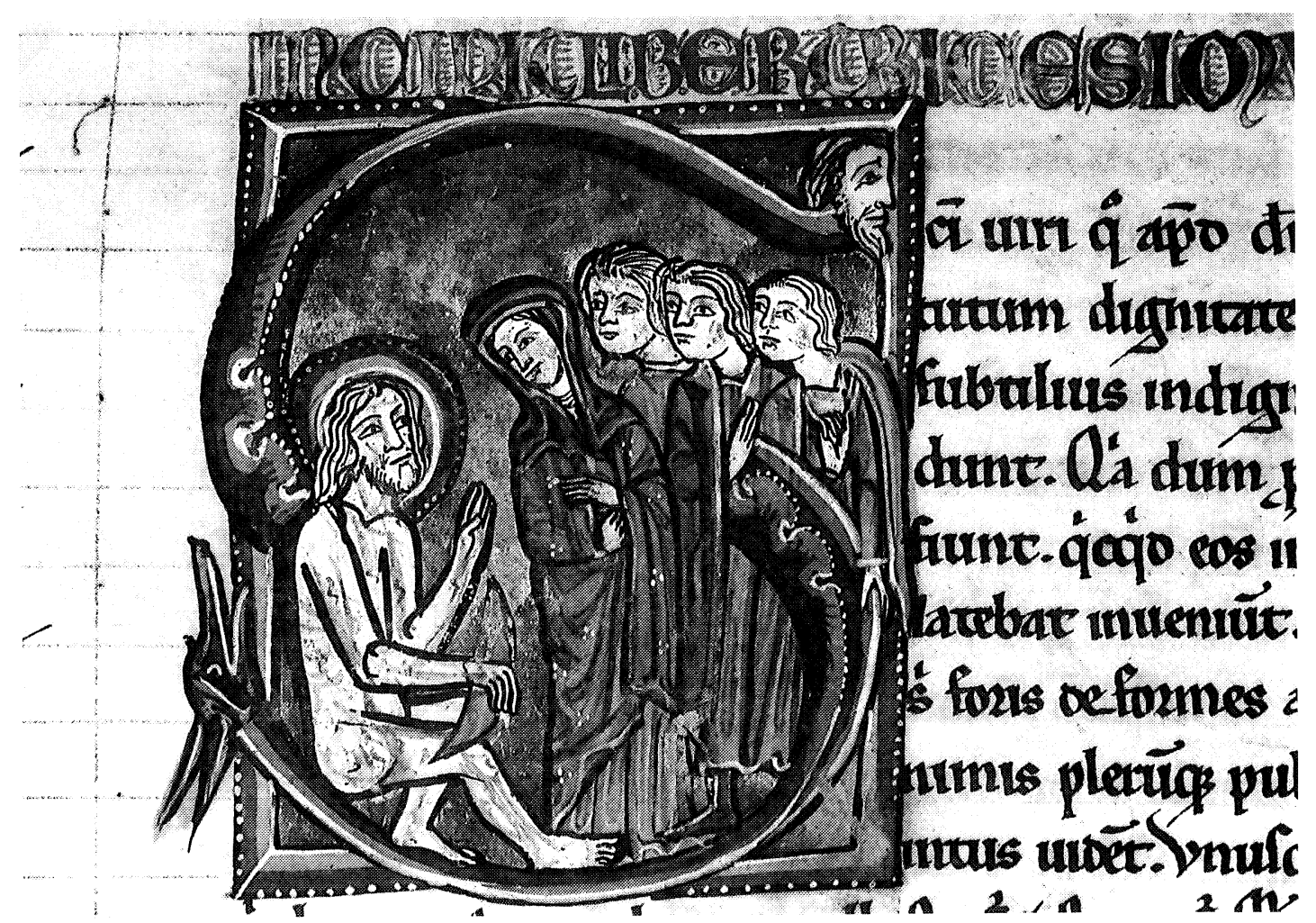

Fig. 4. Job visitado por su mujer y amigos. Morales de San Gregorio. (Madrid, B.A.H., cod. 1, fol. 215v.) 
cenas cuando sólo el primero de los pasajes escriturísticos menciona su presencia. Pero a pesar de la poca importancia que le concedió el texto, no ocurrió lo mismo en el arte medieval donde esta mujer aparece en numerosas ocasiones. La escena debió de hacerse tan popular en la ilustración del libro en aquella época que como vemos se convirtió en un cliché constantemente repetido al margen de que el texto, junto al cual figura la miniatura, la mencionara o no. Sólo esta popularidad del tema puede explicarnos el lugar que ocupa en los «Moralia», el final del capítulo XXXIX y comienzo del XL del Libro de Job (Moralia, Libro XXXII, cap. I) donde se narra el diálogo mantenido entre éste y Dios, y que por lo tanto nada tiene que ver con el contenido de la miniatura. Una de las imágenes más antiguas que conservamos de esta temática nos la proporciona la Biblia catalana de Roda del siglo xI donde podemos ver a Job ulcerado acompañado por su mujer y sus amigos ${ }^{26}$. Otro ejemplo lo encontramos en el Libro de Job traducido al latín por San Jerónimo con glosas extractadas del Comentario de San Gregorio Magno del siglo XII conservado en la Catedral de Pamplona. El manuscrito tiene un dibujo a pluma que representa a Job semidesnudo con su cuerpo cubierto de llagas y un tejón en la mano derecha en presencia de su mujer y sus amigos ${ }^{27}$. A la misma época y entorno pertenece el famoso capitel de Job que lucía en el claustro románico de la citada Catedral de Pamplona que representa entre otras escenas esta misma que venimos comentando: Job en el muladar visitado por su mujer y sus amigos, esta vez en número de cuatro y no tres como es lo habitual ${ }^{28}$. Fuera de la Península, el arte europeo nos proporciona abundantes ejemplos sobre todo miniados de esta misma temática que no vamos a recoger aquí 29

\section{Job visitado por un ángel (fol. 222). (Fig. 5)}

Aunque el texto bíblico no menciona en ningún momento que Job hubiera recibido la visita de un ángel, la presencia de estos seres espirituales acompañan en diversas escenas el ciclo de Job desde tiempos altomedievales. Ya en nuestro arte hispánico la Biblia de Roda compuesta en el siglo XI en Cataluña ya mencionada, efigia una imagen que representa a Job habiendo perdido todos sus bienes y a un ángel mostrándole un objeto simbólico ${ }^{30}$. Un ángel sobrevuela también en este mismo ejemplar el grupo ya comentado, integrado por su mujer y sus amigos, imagen que

26 París, Bibl. Nat. MS. Iat. 6, fol. 63. La escena forma parte de un corto ciclo de Job que incluye la prosperidad de Job en su palacio y la visita de los mensajeros; la pérdida de sus bienes; la prueba de la úlcera y la visita de su mujer y sus amigos y finalmente la restitución de sus bienes. Estas imágenes en esta Biblia no ilustran el Libro de Job sino las genealogías de Paralipomenos. Véase, Neuss, W., Die Katalanische Bibelillustration um Wende des ersten Jahrtausends und die altspanische Buchmalerei, Verlag, Bonn y Leipzig, 1922, fig. 84.

27 Silva Verastegui, S., "Manuscritos ilustrados», en La Catedral de Pamplona, de VV.AA., Pamplona, 1994, págs. 121-122, fig. pág. 121. Sobre él véase también Domínguez Bordona, J., Manuscritos con pinturas. Notas para un inventario de los conservados en colecciones públicas y particulares de España, Madrid, 1933, Il, pág. 124, lám. 525; Goñi Gaztambide, J., Historia de los obispos de Pamplona 1. Siglos IV-XIII, Pamplona, 1979, pág. 493, SILVA Verastegui, S., La miniatura medieval en Navarra, Pamplona, 198X, págs. 105-109; Yarza, J., "La miniatura románica. Estado de la cuestión», en Anuario del Departamento de Historia y Teoría del Arte, II, 1990, pág. 99.

28 Otra escena esculpida parecida nos la proporciona el magnífico capitel de la Daurade (Toulouse, Musée des Augustins) del siglo XII. Véase entre otros estudios Vázquez de Parga, L., "Los capiteles historiados de la Catedral de Pamplona" en Príncipe de Viana, VIII, 1947, págs. 457ss; Gaillard, G., "El capitel de Job en los Muscos de Toulouse y de Pamplona» en Príncipe de Viana, XXI, 1960, pág. 237; Jover, M., "Los cielos de la Pasión y Pascua en la escultura monumental románica en Navarra", en Príncipe de Viana, XLVIII, 1987, págs. 7-40; Fernández Ladrada, Cl., La arqueta de Leyre y otras esculturas medievales en Navarra, Pamplona, 1983; Breeze, A., "Job's gold in Medieval England, Wales and Navarre", en Notes and Queries, 37, n. ${ }^{\circ}$ 3, 1990, págs. 275-278.

29 Una relación de algunas de estas escenas en Yarza, J., "Acotacions iconographiques", op. cit., pág. 70 y especialmente nota 13 .

30 París, Bibl. Nat. ms. Iat. 6, fol. 63. Cfr. Neuss, W., op. cit., fig. 84. 
tiene un paralelo iconográfico en la ilustración del folio 274v de la Biblia de San Millán, donde otro ángel sobrevuela a Job en perfecto diálogo con sus amigos sin que en esta ocasión esté presente su mujer en consonancia con el texto que ilustra Job. 36, ss. Más significativa a nuestro propósito es la escena que figura en el ejemplar de los "Moralia» del Museo Episcopal de Vich (Ms. 26) fechable en el siglo XI donde aparece Job medio desnudo y en la parte superior Dios y un ángel ${ }^{31}$. La colocación de esta escena al final del texto nos permite identificarla con los momentos finales de la prueba a la que este personaje fue sometido cuando Dios mismo le anuncia su fin dándole el premio merecido con la restitución de su salud, de su familia y todos sus bienes perdidos. Un paralelo iconográfico notable nos lo proporciona el mencionado capitel de la Catedral de Pamplona del siglo XII, donde se representa este mismo episodio final mostrándonos a Job desnudo, en pleno proceso de curación pues presenta algunas llagas ya cicatrizadas en presencia de Dios y un ángel. Pero el ejemplo más cercano iconográficamente al de nuestra miniatura es otro capitel algo más tardío que el pamplonés, el de la Daurade de Toulouse, que recoge este momento final del ciclo de Job representando a éste semidesnudo ante la sola presencia de un ángel ${ }^{32}$. Como vemos la escena esculpida recuerda vivamente a la que reproduce nuestra miniatura protagonizada también exclusivamente por Job semidesnudo, sentado sobre una banqueta ante un ángel que aparece en pie frente a él. Ambas escenas representan el final de los padecimientos de Job que un ángel le anuncia.

Vemos pues, que aunque el tema con la presencia del ángel fue posiblemente una invención del arte medieval, conoció cierta difusión y que el miniaturista de los «Moralia» lo utilizó para simbolizar el final de los males de Job que el mismo ángel le anunciaba. Quedaba en este caso también justificada su posición en el texto al ilustrar precisamente los capítulos finales del Libro de Job (Moralia, Libro XXXIII, cap. I).

\section{La Virgen con el Niño y un monje a sus pies (fol. 236). (Fig. 6)}

Una de las miniaturas más sorprendentes de este ejemplar de los "Moralia» es esta imagen que representa a la Virgen sedente con el Niño en su regazo, y al lado un monje arrodillado, efigiado a escala ostensiblemente menor. Sobre fondo dorado destaca el azul de la túnica de la Virgen que lleva la cabeza cubierta con un velo verde que cae sobre los hombros, y una corona roja encima. En la mano derecha sostiene un gran florón. El Niño aparece vestido con túnica verde, bendice con la mano derecha y lleva un libro en la izquierda. El monje viste el hábito negro de los benedictinos con capucha sobre la cabeza. La imagen no puede ser más desconcertante, pues ninguna referencia directa a la Virgen recoge el texto en este capítulo final (la miniatura ilustra el inicio del Libro XXXV). Sin embargo, un paralelo interesante nos lo proporciona otro bellísimo ejemplar de los "Moralia» en Job (Cambridge, Emmanuel College Ms. II. 1.1) fechado también en el siglo XIII que presenta al comienzo del Libro XXVI una imagen de Cristo en pie a quien adoran dos monjes benedictinos arrodillados con las manos juntas en actitud de oración ${ }^{33}$. La inserción de este tipo de imágenes en los «Moralia in Job» es posible que deriven de escenas de dedicación del códice de las que tenemos ejemplos miniados desde época altomedieval. Muy significativa a nuestro respecto, es la imagen que reproduce el manuscrito de los "Moralia» (Einsiedeln, Stiftsbibliothek, MS. 151) de la segunda mitad del siglo XI donde aparece el Papa Grego-

\footnotetext{
31 Vid. Gudiol i Cunill, J., La pintura medieval catalana, vol. III. Els Primitius 3. Els Libres illuminats, Barcelona, 1955, pág. 109 , fig. 69

32 Cfr. Gaillard, G., «El capitel de Job», op. cit., pág. 238.

33 Cfr. Brieger, P., English Art 1216-1307. The Oxford History of English Art, ed. T. S. R. Boase, Oxford and Claredon Press, 1962 (1.a ed. 1957), pág. 219, lám. 89.
} 
W(A)

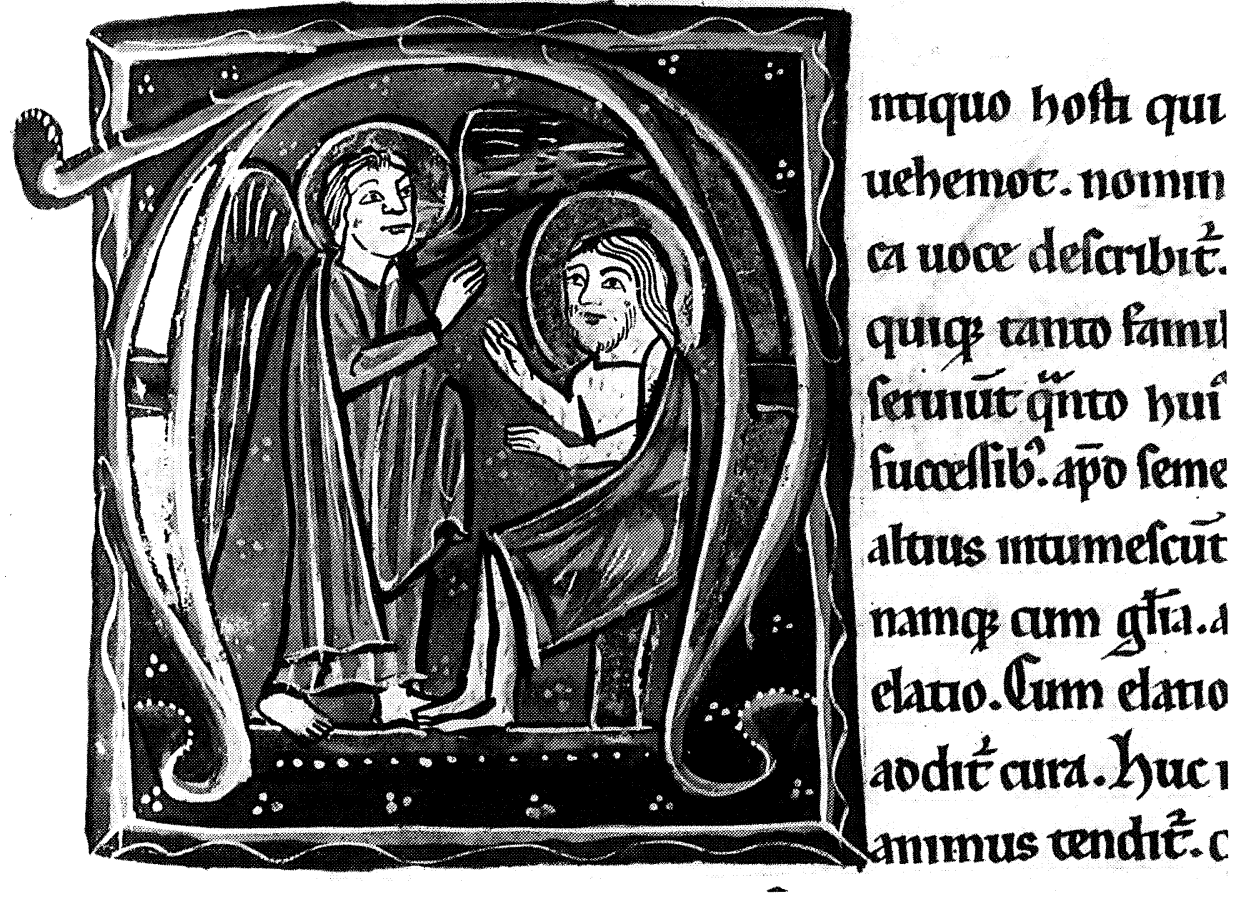

Fig. 5. Job visitado por un angel. Morales de San Gregorio. (Madrid, B.A.H., cod. 1, fol. 222.)
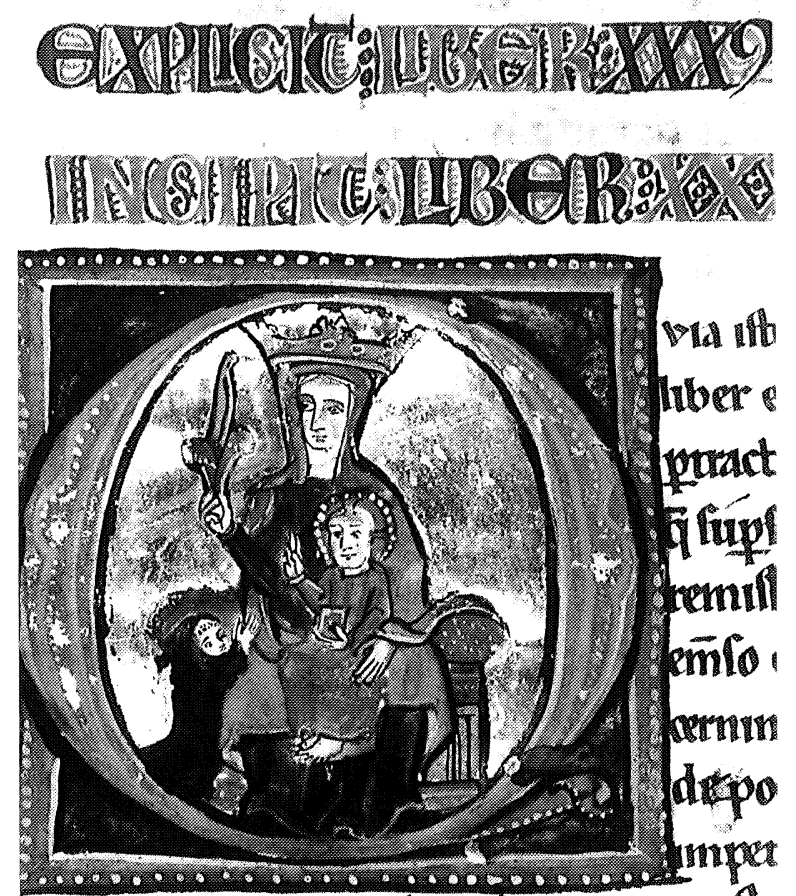

ge impulfione pattini fiatus imus. 0 .

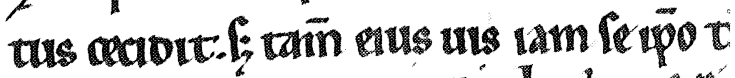

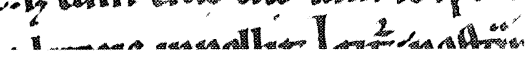

Fig. 6. Virgen con el Niño y un monje. Morales de San Gregorio. (Madrid, B.A.H., cod. 1, fol. 236.) 
rio acompañado por su escriba dedicando la obra a una imagen de la Virgen con el Niño ${ }^{34}$. Pero a parte de estos precedentes visuales la imagen de la Virgen y el Niño que representa el ejemplar de nuestros «Morales» encuentra plena justificación en nuestro manuscrito por el ambiente de intensa devoción mariana que se respiraba en el monasterio de San Millán de la Cogolla en los primeros decenios del siglo xiII y de la que constituye un brillante testimonio los poemas marianos que Gonzalo de Berceo escribe en este mismo entorno en estos años. Precisamente los autores han visto en estas composiciones literarias un eco fidedigno de la profunda espiritualidad mariana que se vivía desde tiempo atrás en e] viejo cenobio benedictino ${ }^{35}$. La miniatura se ha colocado al comienzo del libro XXXV.

\section{La ornamentación}

En contraste con la sobriedad decorativa que presenta el ejemplar de los "Moralia» del siglo $\mathrm{x}$ del que se obtuvo, como hemos dicho, esta nueva copia del siglo xiII, este manuscrito ofrece una extraordinaria decoración de iniciales colocadas al frente de cada uno de los treinta y cinco libros que incluye el códice. Algunas han sido bárbaramente mutiladas ${ }^{36}$. Aunque sabemos de la existencia de ejemplares de los «Moralia» cuyas iniciales -en apariencia meramente ornamentales-, responden a profundos conceptos teológicos entresacados de la exégesis alegórica que el Papa Gregorio hizo al Libro de Job, las iniciales del manuscrito emilianense no parece que rebasaron su finalidad estrictamente decorativa ${ }^{37}$.

Como es usual en la ornamentación de iniciales de la época todas se hallan enmarcadas por encuadres de diversas formas geométricas muy parecidos a los de la Biblia de San Millán. Sus fondos se encuentran también coloreados en azul, verde y oro y en alguna ocasión en rojo, decorados además con adornos de tres puntos blancos. Como en la Biblia mencionada los motivos decorativos predominantes son los vegetales que agrupados en ramos de tres o más hojas sirven de relleno a los espacios que dejan libres las líneas estructuradoras de los trazos principales de las letras ${ }^{38}$. A ellas, como en la Biblia emilianense se asocian numerosos dragones alados cuyos cuellos y colas se estiran para adaptarse a aquellas, muchas veces originando bellísimas composiciones en espiral. Ya hemos dicho en otro lugar a propósito de la Biblia de San Millán que estos motivos vegetales y los dragones alados constituyen el «leiv motiv» de la decoración de iniciales de los manuscritos de principios del siglo XiII. Iniciales muy bellas son las de los folios 16v en la que dos dragones afrontados en torno a un vástago floral que se origina de sus colas, se muerden sus propios cuellos, otro su cola, dos más las colas de sus congéneres y por último otro el trazo vertical de la inicial, o la del folio 76 en la que de nuevo otros dos dragones desarrollan una gran espiral a la que se integran motivos vegetales cuyas hojas presentan también los bordes

34 Ernest, T. de Wald, "The art of the scriptorium of Einsiedeln». The Art Bulletin, VII, 1924-25, fig. 27. Véase también, Prochno, J., Das Schreiber und Dedikationsbild in der Deutschen Buchmalerei 1. feil. Bis zum ende des 11 Jahrhunderts (800-1100), Verley, 1929, pág. 24.

35 No olvidemos que la Iglesia del monasterio de San Millán de Yuso estaba dedicada desde el siglo XI a la Virgen. En 1241 el prior D. Rodrigo dejó una lámpara que ardiese delante de la imagen de la Virgen que se situaba en el claustro del cenobio. Cfr. Dutton, B., La "Vida de San Millán de la Cogolla» de Gonzalo de Berceo, Estudio y Edición crítica, London, 1967, págs. 166-168.

36 Han sido arrancadas las iniciales de los folios $116,142,161$ y $230 \mathrm{v}$.

37 Sobre este aspecto puede verse Davidson, C.T., "Sources for the initials of "Citeaux" Moralia in Job", en Studies in cistercian art and architecture, III, Kalamazoo, Michigan, 1987, págs. 46-68. Para la Influencia de los "Moralia» en el románico, Angheben, M., "Le combat du guerrier contre un animal fantastique: à propos de trois chapiteaux de Vezelay”, en Bulletin Monumental, 152, 1994, págs. 245-256.

38 Iniciales exclusivamente vegetales son las de los folios 99 y 183 ; la mitad del folio $94 \mathrm{v}$ incorpora dos pequeños dragoncillos. 
dentados y otros adornados con puntos blancos muy característicos. Como en la Biblia emilianense con cuyas iniciales presentan notable parecido, es frecuente que estos seres fantásticos tengan cabeza de perro (fol. 30v, 73, 105), obsérvese las semejanzas entre esta última inicial comentada y la B del folio $280 \mathrm{v}$ de la mencionada Biblia. En ocasiones estos dragones dan pie a bellísimos juegos de líneas serpentinadas como la inicial que nos proporciona el folio 105, una $\mathrm{Q}$ cuyo trazo inferior lo constituye un dragón alado cuya cola remata en otra cabeza similar de animal perruno que a su vez muerde el cuello de una tercera bestia fantástica que vomita de su boca otro dragoncillo con la cabeza convertida en un ramo vegetal. El cuerpo de la inicial se rellena con tallos dispuestos en róleos que terminan en motivos florales. Otra inicial similar es la Q del folio 110v cuyo trazo inferior lo configura otro dragón alado cuyo cuerpo describe una línea sinuosa dispuesta en vertical y su cola remata en la consabida composición vegetal. En cambio la $\mathrm{Q}$ del folio $129 \mathrm{v}$ despliega su ornamentación en el cuerpo de la inicial compuesto por una serie de tallos dispuestos en róleos salpicados por hojas de bordes también dentados a los que se asocia un gran dragón alado con cabeza perruna y patas de cuadrúpedo que gira su cabeza para morderse las alas. Semejantes a esta última son las iniciales de los folios $155,174 \mathrm{v}$ y $188 \mathrm{v}$. También responde al mismo tipo de inicial la $\mathrm{S}$ del folio 40 diseñada con la figura de otro dragón alado y cuyos espacios libres se rellenan con róleos y composiciones vegetales.

A veces a estos motivos se les añaden otros, ya sean cuadrúpedos, o alguna que otra máscara fantástica. Ejemplos de los primeros nos lo proporcionan los folios 54 y 121 que recuerdan a alguna inicial de las Vitae Patrum (B.A.H., cod. 10) otro de los manuscritos que se copia en el escritorio monástico también por estos años. Ambos casos reproducen una $\mathrm{P}$ cuyo trazo vertical sale de la boca del cuadrúpedo desarrollándose después en el cuerpo de la inicial los motivos de la fauna y flora comentada. A éstas puede asociarse también la inicial del folio 65 en la que dos cuadrúpedos rellenan el cuerpo de la letra. Muy bella es la inicial $\mathrm{M}$ del folio 89 que representa una máscara frontal, única cabeza de dos dragones rampantes que diseñan los trazos laterales de la inicial mientras el del medio lo constituye un vástago floral que sale de las fauces de la máscara. El espacio libre se cubre con oro y se rellena con otros dos dragones cuyas colas engendran diversas composiciones vegetales. Una inicial con el motivo central parecido nos lo proporciona la Historia Scholastica de Pedro Comestor (B.A.H., cod. 11), otra de las obras que también se copian a principios del siglo XIII en el escritorio de San Millán, si bien difiere de nuestro ejemplar el diseño y colorido. Muy original, es la inicial del folio $22 \mathrm{v}$ que representa un dragón alado ocupando el trazo vertical de la $\mathrm{P}$ y dos palmípedos en el cuerpo de la letra con sus largos cuellos doblados hacia atrás bebiendo de una fuente. En alguna ocasión, como en la Biblia de San Millán, cuando la inicial es una I ésta se decora con un motivo único el dragón alado cuya cola desarrolla róleos vegetales más o menos abundantes. Obsérvese el parecido de nuestra inicial del folio 138 con la del folio 110 en el incipit del Libro de Ester de la Biblia emilianense (vol. II).

La fantasía decorativa de los miniaturistas de los "Moralia» alcanza su punto álgido en las iniciales de los folios 196 y 205 que representan sendas arpías con su cuerpo enmarañado entre composiciones vegetales dispuestas en róleos que tienen también sus paralelos en algunas iniciales de la Biblia (Vol. II, fols. 29 y 116). Entre las iniciales decoradas con motivos antropomórficos destacan las de los folios $82 \mathrm{v}$ y 149 . La primera desarrolla, ocupando el cuerpo de la inicial, sobre fondo de oro, una composición floral con róleos que rematan en tres cabezas humanas y la segunda asocia a los habituales motivos vegetales y el dragón alado un ser humano de cuerpo entero desnudo que tiene también su paralelo con otra inicial de la Historia Scholastica pero con la que no existe más relación que la utilización del mismo motivo. Como en la Biblia de San Millán todas estas iniciales decorativas presentan notable paralelismo con las que reproducen los manuscritos ingleses y del Norte de Francia a principios del siglo xiII, de modo que cabe hablar de una influencia inglesa ope- 


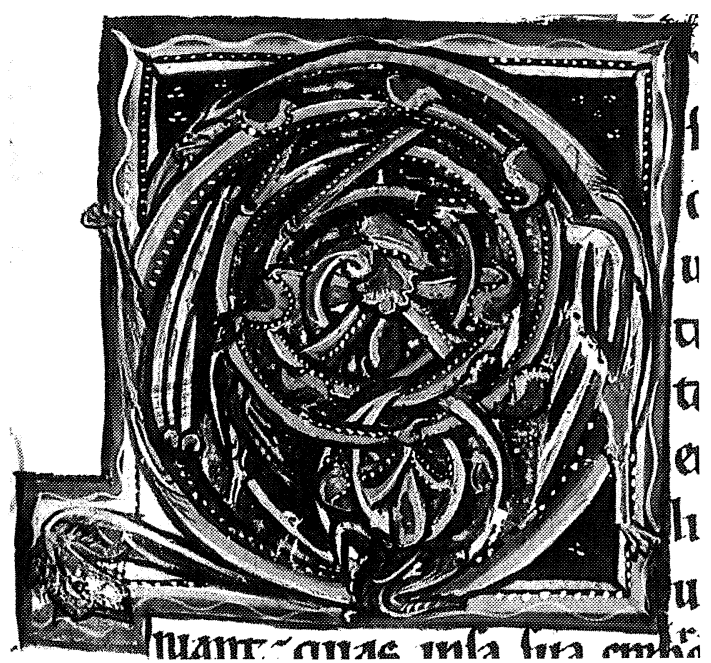

7

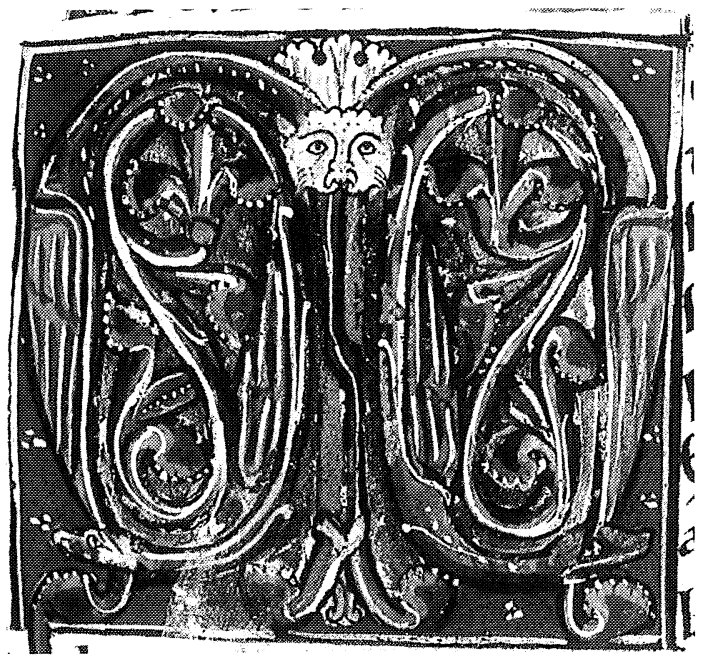

8

9
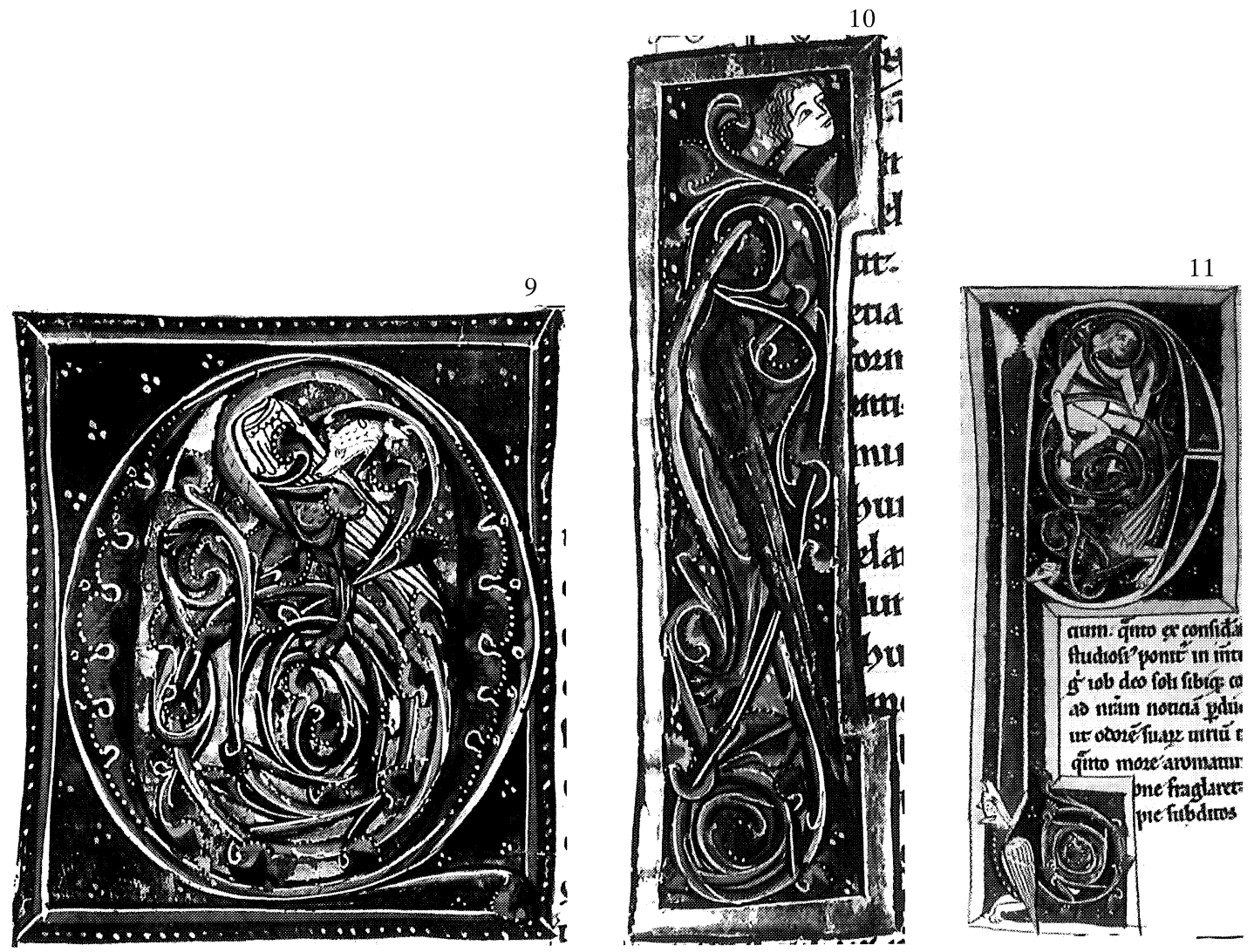

Figs. 7-11. Iniciales. Morales de San Gregorio. (Madrid, B.A.H., fols. 76, 89, 129v, 205 y 149.) 
rante en nuestro escritorio rebasado el $1200{ }^{39}$. Estos contactos no nos extrañan si tenemos en cuenta la llegada por estos mismos años de manuscritos ingleses a la vecina región castellana burgalesa como recientemente ha puesto de manifiesto el prof. Yarza a propósito del espléndido Martirologio descubierto hace unos años en el Monasterio de las Huelgas y de otros códices hispanos realizados en dicho scriptorium fuertemente influidos por la misma área europea señalada 40 .

\section{El estilo y los miniaturistas}

La decoración de este magnífico ejemplar de los "Moralia» ha sido llevada a cabo por los mismos miniaturistas que han intervenido en la Biblia de San Millán. Así en las miniaturas pueden reconocerse las dos manos principales que hemos detectado en aquélla ${ }^{41}$. Al primer maestro (Maestro A) le corresponde sin duda, la escena de «Job visitado por su mujer y sus amigos» cuyos personajes reproducen los mismos rasgos característicos que vimos en aquél: los ojos están formados por dos líneas, semicircular la superior y rectilínea la inferior marcándose la pupila con un punto negro. El mismo trazo delimita la nariz que remata en la consabida línea sinuosa y una de las cejas. Dos trazos, el superior recto y el inferior corto y curvo forman la boca. Muy característico es también el modo de disponer el cabello formado aquí igualmente por una serie de líneas paralelas sinuosas que descienden en ondas sobre el rostro, tapando las orejas. Su estilo se advierte también en el plegado de los ropajes marcados por pinceladas más o menos largas y gruesas más intensas de color pero del mismo tono aplicado a las diferentes prendas -túnicas y mantos-. El dibujo negro grueso y firme marca únicamente las líneas esenciales. A la misma mano se pude atribuir "la visita del ángel a Job» y «Job y el demonio» si bien el estado de conservación de esta última nos impide ver los rasgos del rostro tan característicos de su modo de hacer. Estos se perciben igualmente en la primera miniatura que representa «un obispo y dos clérigos» y en los rostros antropomorfos que reproducen algunas iniciales ornamentales como los de las arpías de los folios 196 y 205, las tres cabezas humanas que se agrupan en la inicial del folio $82 \mathrm{v}$ o el del personaje desnudo enmarañado entre tallos y róleos del folio 149. Es posible que a este miniaturista se le deba la mayoría de las iniciales ornamentales que presentan varios puntos en común con las de la $\mathrm{Bi}$ blia hasta el punto de hacernos pensar, como venimos diciendo, en la participación del mismo taller o equipo de ilustradores. La intervención del segundo maestro (Maestro B) que trabajó en la Biblia es aquí esporádica limitándose a una única miniatura «San Gregorio como autor inspirado». Basta comparar su retrato con el de personajes como el faraón en las miniaturas del Exodo de la Biblia (fol. 40v) para darnos cuenta de que ambos son obra de la misma mano. Todavía cabria ver una tercera mano mucho más tosca en la imagen de «la Virgen y el niño» comentada.

Como hemos visto pues, a principios del siglo XIII se renuevan en el scriptorium de San Millán de la Cogolla las labores de ilustración y ornamentación de manuscritos produciéndose obras, como el espléndido códice que aquí hemos dado a conocer, que supone desde el punto de vista artístico la actualización de los viejos sistemas ilustrativos que tanto arraigo tuvieron como es sabido en el monasterio, incluso en estos años, incorporando junto a ellos el tipo de decoración en boga en la miniatura europea de la época, tal como este ejemplar testimonia.

\footnotetext{
39 A parte de la decoración de iniciales, hemos detectado influencias inglesas en !a ilustración del Génesis de nuestra Biblia.

40 Véase, Herrero, S., Códices miniados en el Real Monasterio de las Huelgas, Madrid-Barcelona, 1988; Yarza, J., "La miniatura en los reinos de León, Galicia y Castilla en tiempos de Maestro Mateo", O Portico da Gloria e a Arte do seu tempo, Santiago de Compostela, 1988, págs. 324-325; Idem, "La miniatura románica», op. cit., pág. 14; Idem, "Códices miniados en el Monasterio de las Huelgas», en Reales Sitios, 107, 1991, págs. 45-56.

41 Hemos llevado a cabo el estudio de esta Biblia en nuestro trabajo Contribución al estudio de los manuscritos ilustrados en San Millán de la Cogolla en los siglos xI al xIII (en prensa).
} 